\title{
BMJ Open Association between caring for grandchildren and feelings of loneliness, social isolation and social network size: a cross-sectional study of community dwelling adults in Germany
}

\author{
Eleanor Quirke (D) , Hans-Helmut König, André Hajek 도
}

To cite: Quirke E, König H-H, Hajek A. Association between caring for grandchildren and feelings of loneliness, social isolation and social network size: a cross-sectional study of community dwelling adults in Germany. BMJ Open 2019;9:e029605. doi:10.1136/ bmjopen-2019-029605

- Prepublication history for this paper is available online. To view these files, please visit the journal online (http://dx.doi. org/10.1136/bmjopen-2019029605).

Received 01 February 2019 Revised 05 November 2019 Accepted 06 November 2019

Check for updates

(C) Author(s) (or their employer(s)) 2019. Re-use permitted under CC BY-NC. No commercial re-use. See rights and permissions. Published by BMJ.

Department for Health

Economics and Health Services Research, Universitatsklinikum Hamburg-Eppendorf, Hamburg, Germany

Correspondence to

Ms Eleanor Quirke;

e.quirke@uke.de

\section{ABSTRACT}

Objective The aim of this study was to examine whether there is an association between grandparental care and Ioneliness, social isolation and/or the size of an individual's social network among community-based adults aged $\geq 40$ years.

Methods Cross-sectional data were drawn from a population-based sample of individuals aged $\geq 40$ years living in the community in Germany. Loneliness was measured using a short version of the De Jong Gierveld Loneliness Scale. Social isolation was measured using a scale developed by Bude and Lantermann. The number of important people with whom respondents have regular contact (ie, social network size) was also used as an outcome variable. All respondents were asked whether they privately provide grandparent care (no/yes).

Results Linear regressions showed reduced loneliness $(\beta=-0.06, p<0.01)$ and social isolation scores $(\beta=-0.04$, $p<0.05$ ) among those undertaking care of a grandchild. Regression analysis also showed an increased number of important people with whom individuals had regular contact among those who undertook care of a grandchild $(\beta=1.02, p<0.001)$.

Conclusion Findings indicate a positive association between undertaking the care of a grandchild and the size of an individual's social network, and a negative association between grandchild care and self-rated scores of Ioneliness and social isolation. These findings build on existing research into the social and health implications of grandchild care among grandparents. Longitudinal studies are required to strengthen the understanding of this association.

\section{INTRODUCTION}

The grandparent role has been described as an important and rewarding role among ageing individuals. ${ }^{1}$ Grandparenthood can be a source of rewards, such as company, feeling useful and discovering new abilities in oneself. ${ }^{2}$ The provision of grandparental care is considered a serious and demanding aspect of this role, ${ }^{3}$ and is a central aspect of supporting participation of parents in the job
Strengths and limitations of this study

- Data drawn from a large nationally representative sample of community-dwelling German individuals.

- Validated tools used for the measurement of loneliness and social isolation.

- Due to its cross-sectional nature, it is difficult to draw conclusions regarding the direction of association between variables.

- There is the possibility of selection bias in the data.

market. Increases in life expectancy and the changing role of women in the workforce have led to a greater demand for the provision of childcare by grandparents, ${ }^{4-7}$ particularly in jurisdictions where the provision of public childcare is insufficient. $^{3}$

In view of these changing dynamics, the implications of the provision of grandchild care for grandparents have been the subject of growing research interest. The literature to date can be roughly divided into two categories: studies that consider the implications of very intense grandparental caregiving (ie, surrogate parents or grandparents who assume responsibility for raising their grandchildren) and studies that consider the implications of the provision of supplementary parental care (ie, care provided on occasions when parents are not available or other forms of care cannot be sourced). The majority of the literature has focused on the first category. However, as noted by Muller and Litwin, it is in fact more common for grandparents to provide supplementary care to their grandchildren. ${ }^{8}$ In the USA almost $50 \%$ of grandparents provide some degree of childcare. ${ }^{9}$ A similar proportion of grandparents in Europe also provide care for their grandchildren, although the proportions vary between countries. ${ }^{3}$ Data on the exact number of 
grandparents in Germany are not available. In 2014, 23\% of respondents to the German Ageing Survey (DEAS) reported not having grandchildren, with the DEAS survey considered to be representative of the German population aged $>40$ years. ${ }^{10}$

Some studies have considered the broader implications of undertaking supplementary grandchild care, including the effect that such an undertaking would have on a grandparent's social activities. Bulanda and Jendrek found that grandparental caregiving was associated with a higher likelihood of volunteering. ${ }^{11}$ On the other hand, Albertini and Kohli showed in their 2009 study that the provision of grandchild care by women negatively affected the number of social activities with which they engaged. ${ }^{12}$ With respect to the implications of undertaking supplementary grandchild care on social links, Triado et al concluded in their study on the satisfaction among grandparents of providing grandchild care as well as the impact of providing such care on their health and well-being, that providing grandchild care seems to be an opportunity for grandparents to 'establish and reinforce affective links, rather than a burden or potentially stressful task'.13

Many studies have used the concepts of role strain and role enhancement to explain the health and psychological implications of grandparental caregiving in a number of studies. ${ }^{14}$ Central to both theories is the notion that individuals occupy multiple social roles that carry with them obligations and rewards. Role strain theory posits that occupying multiple social roles requires the individual to juggle conflicting and demanding obligations, which can overload or strain the individual and act as a stressor, leading to negative health implications. Role enhancement theory posits that occupying many roles is beneficial to the health of the individual, as occupying many social roles enhances their personality, contributing to positive self-esteem. ${ }^{15}$ One example of this is a study that longitudinally assessed the impact of intensive and non-intensive grandparental caregiving on health. In this study the authors used role strain and enhancement theory as a possible explanation for why grandparents providing less intensive care for their grandchildren might experience better psychological health than those who provide more intensive or surrogate care for their grandchildren. ${ }^{16}$ To the best of our knowledge, no research has been conducted to date that explores the impact of supplementary grandchild care on the social relations of grandparents. The most relevant study for this particular area of interest is that of Tsai et al who, in their longitudinal study using data drawn from a populationbased survey, found that providing grandchild care was associated with lower loneliness scores among grandparents living in Taiwan. ${ }^{17}$ However, the focus of this study was the impact of grandchild care on depression, and respondents to the survey were only asked one question pertaining to feelings of loneliness-that is, scores pertaining to loneliness were calculated as an aspect of the tool used in the study to measure depression.
Moreover, the study did not consider the implications of grandchild care on more objective measures of social relations, including the size of the grandparent's social network. Indeed, to date, no studies have explored the association between grandchild care and the size of the grandparent's social network.

This study therefore aims to explore whether provision of grandchild care is associated with objective and subjective measures of social relations-namely, feelings of loneliness, the size of one's social network and social isolation. Loneliness among older individuals is an emerging issue, and a growing body of literature has pointed to clear links between loneliness, social isolation and poor health outcomes. ${ }^{18-21}$ Moreover, social activities in later life have been identified as a relevant aspect of active and successful ageing frameworks. ${ }^{22}{ }^{23}$ Furthermore, the need for further understanding of the role of social support in shaping the well-being of grandparents has been identified. ${ }^{24}$ In their 2006 study, Gerard, Landry-Meyer and Roe found that enacted social support-namely, the number of supportive transactions an individual has engaged in as a recipient-buffered the impact of grandchild and parenting hassles on caregiving stress and life satisfaction. However, they identified that further research in this field was required to better understand the positive effects that more social resources have on grandparents who providing caregiving. ${ }^{24}$ The findings of this study will therefore contribute to knowledge on protective and positive lifestyle factors for individuals in the later stages of life.

\section{METHODS}

This study analysed data collected via the DEAS survey, a cohort-based longitudinal survey of community dwelling adults in Germany aged $\geq 40$ years. The survey was initiated in 1996, with the view to providing a representative national database that described the living conditions of middle-aged and older populations, and that could be used for research into the process of ageing and its effects on individuals and processes of social change. ${ }^{25}$

The survey has a cohort-sequential design, comprising cross-sectional samples (baseline samples) and panel samples. Participants are followed over time and surveyed again in subsequent waves (from 2008, this has been every 3 years). To date, the DEAS has consisted of five waves (in 1996, 2002, 2008, 2011 and 2014). Baseline samples are drawn from a randomly drawn sample of 290 municipalities in Germany (of which there are a total of 12000 ) and are disproportionately stratified into three age groups (40-54, 55-69 and 70-85 years), gender and region.

This study used data drawn from the fifth wave of the study (2014). This set of data was used as it was the first instance in which social isolation was measured. The response rate in 2014 was $25 \%$ for the cross-sectional panel and $61 \%$ for the panel sample ${ }^{26}$ (see Klaus et al for further details regarding the study). ${ }^{25}$ 


\section{Patient and public involvement}

Neither patients nor the public were involved in the development of the methodology for the current study; however, the experiences of community-dwelling adults in older age, as described in the current literature, informed the development of the research question and selection of appropriate outcome measures.

\section{Ethics approval}

This study did not meet the threshold for requiring ethics committee approval (ie, risk for the respondents, lack of information about the aims of the study, examination of patients). All subjects were required to provide written informed consent prior to participation.

\section{Dependent variables}

Three measures were used to quantify social relations among those who cared for their grandchildren, including both subjective and objective measures of social relations. The three measures were chosen to give a comprehensive understanding of the impact of the independent variable on social relations. Loneliness refers to the subjective state of feeling alone, as well as the feeling of lesser social contact than desired or where the quality of social relationships is felt wanting. ${ }^{27}$ Social isolation refers to the feeling of not belonging to society. ${ }^{27}$ Although sometimes used synonymously, ${ }^{28}$ loneliness and social isolation refer to two distinct concepts. ${ }^{29}$ The distinction between all three concepts is evidenced by their inconsistent correlation. It has been evidenced that, while some individuals may be objectively socially isolated and content, others may have frequent social contact but still feel lonely. ${ }^{20}$ Other studies have found that those with fewer people in their social network are more likely to feel lonely than those who have a large social network. ${ }^{30}$ Moreover, research has also shown that the composition of the social network is an important indicator for loneliness. ${ }^{31}$ Finally, social network size represents an objective measure of the number of contacts a person has.

Loneliness was measured using a shortened version ${ }^{32}$ of the De Jong Gierveld Loneliness Scale. ${ }^{33}$ Participants were asked to rate the strength of their agreement on a scale of 1-4 (with 1 representing 'strongly agree' and 4 representing 'strongly disagree') with the following statements: "I miss having people around among which I feel comfortable", "There are plenty of people I can rely on when I have problems", "I often feel rejected", "There are many people I can trust completely", "I miss emotional security and warmth", "There are enough people I feel close to". If a respondent gave a score of $\leq 2$ to more than two statements, a loneliness score would not be calculated. Higher scores represent a higher degree of perceived loneliness. Cronbach's $\alpha$ for this measure was 0.83 in the present study.

The second measure used was the Bude and Lantermann scale measure of social isolation. ${ }^{34}$ Participants were asked to rate the strength of their agreement on a scale of 1-4 (again, with 1 representing 'strongly agree' and 4 representing 'strongly disagree') with the following statements: "I am worried about being left behind", "I feel like I do not really belong to society", "I feel that I am left out", and "I feel excluded from society". Higher scores using this measure refer to a higher degree of perceived social isolation. Cronbach's $\alpha$ for this measure was 0.88 in the present study.

Social network size was measured using a tally of the total number of important people with whom participants were in regular contact (maximum tally of 9).

\section{Independent variables}

The independent variable of interest in this study was undertaking care of a grandchild. Respondents were asked: "I'd now like to go on to learn more about your activities and pastimes. Do you supervise other people's children privately, for example, your grandchildren, or the children of siblings, neighbours, friends or acquaintances?" Those who responded that they supervised their grandchildren or their grandchildren and other children were coded as 1 . The remainder were coded as 0 .

It is well recognised that a number of social and demographic factors can influence feelings of loneliness, social isolation as well as the size of one's social network. ${ }^{28} 2935-37$ Moreover, a number of sociodemographic factors shape the likelihood of a grandparent caring for their grandchild. ${ }^{3-5} 9$ 38-42 On this basis, a number of variables were controlled for in the regression analysis, including age, sex, marital status (married, living together with spouse, other (divorced, widowed, single, married, living separately to spouse) and socioeconomic status (measured using monthly net equivalent income in Euros). In addition, self-rated health ( $1=$ very good to $5=$ verybad), number of physical illnesses (0-11, for example diabetes, cancer), body mass index, frequency of physical activity (daily, several times a week, once a week, 1-3 times a month, less frequently, never) and depressive symptoms (the Centre for Epidemiological Depression Scale (CES-D) was used, ${ }^{43}$ which consists of 15 items with scores ranging from 0 to 45 ; higher scores refer to more severe depressive symptoms) were also controlled for in the regression analysis. In a second regression analysis, the variable 'physical functioning' (subscale of the SF-36 with scores ranging from 0 to 100 ; higher values refer to a higher degree of physical functioning) was added to the model. Physical functioning was only included in the second analysis due to the simultaneity bias between physical functioning and loneliness. ${ }^{44}$

\section{Statistical analysis}

Descriptive statistics for our analytical sample (individuals included in the regression analysis) were first computed ( $\mathrm{n}=3849$ when loneliness served as outcome measure), stratified by those who undertook care of their grandchildren and those who did not (table 1). We checked the normality of residuals using q-norm and kernel density plots. According to these plots, the residuals have an approximately normal distribution. Therefore multiple linear regressions were 


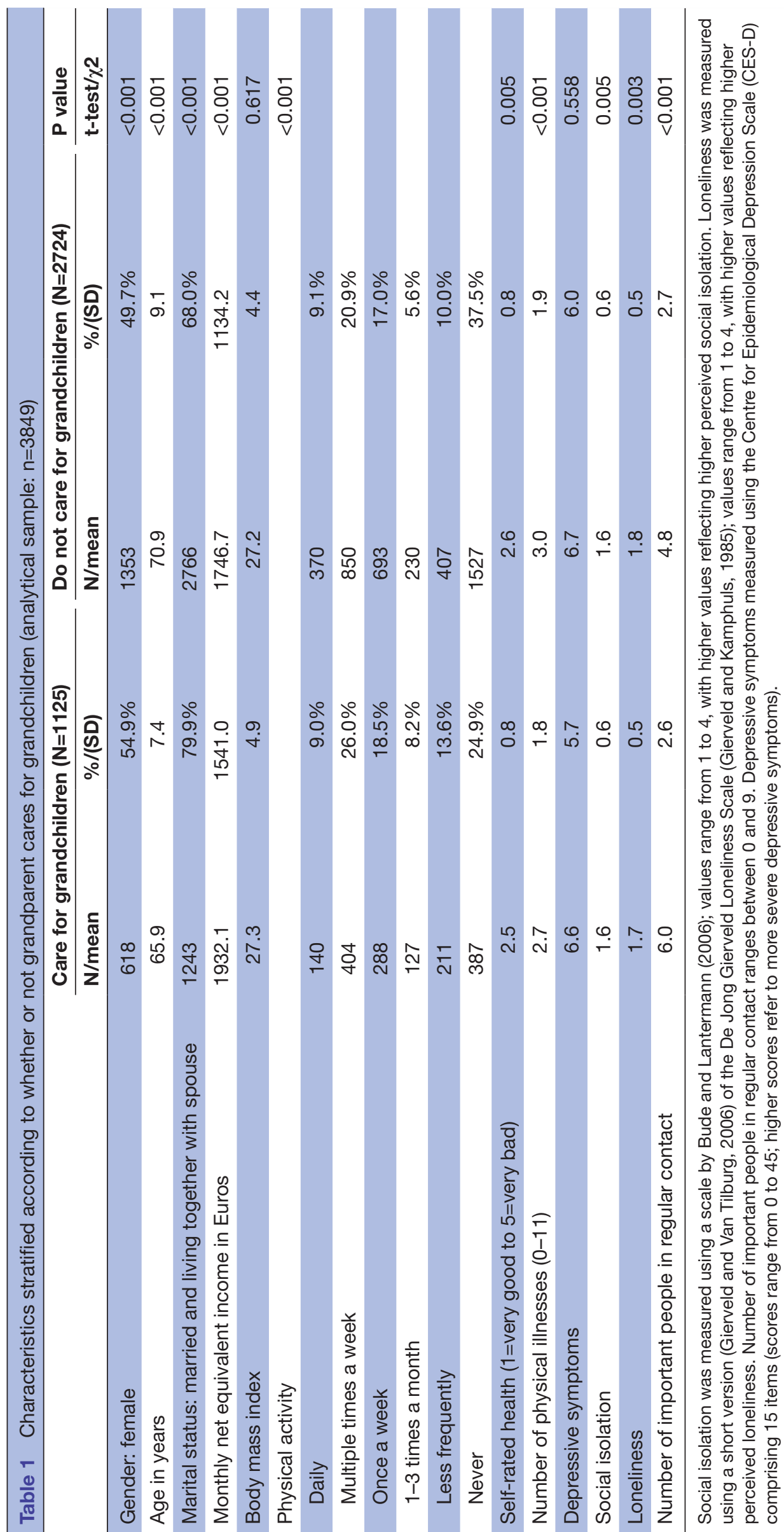


used to model the associations between caring for grandchildren and (1) loneliness, (2) social isolation and (3) social network size, controlling for potential confounders. Listwise deletions were carried out to manage missing values. The analytical sample for the regression analysis had an average of around 3900. The statistical significance was set at $p<0.05$. Statistical analysis was performed using Stata 15.1 (Stata Corp, College Station, Texas, USA).

\section{RESULTS}

In our analytical sample, 1125 of a total of 3849 surveyed grandparents reported that they had cared for a grandchild. Just over half of these respondents were female and just under $80 \%$ were married or living together with a spouse. The mean age among those who cared for grandchildren was about 66 years. The mean loneliness score of those who cared for a grandchild was 1.7, the mean social isolation score was 1.6 and the mean number of people in regular contact was 6.0. Those who did not care for a grandchild reported higher scores for loneliness (1.8) and the mean number of important people with whom they had contact was lower than their counterparts who provided grandchild care (mean score 4.8).

\section{Regression analysis}

The results of the regression analysis are depicted in table 2. After controlling for potential confounders, linear regression analysis showed reduced loneliness $(\beta=-0.06, p<0.01)$ and social isolation scores $(\beta=-0.04$, $\mathrm{p}<0.05)$ among those undertaking care of a grandchild. Regression analysis also showed an increased number of important people with whom individuals had regular contact among those who undertook care of a grandchild $(\beta=1.02, p<0.001)$. All outcomes measures were significantly associated with age, net monthly income and the number of physical illnesses. In an additional analysis the variable 'physical functioning' was added. This addition did not significantly alter the association between our independent variable and the outcome measures (results not included but available on request).

In a sensitivity analysis we restricted our analysis to those who only care for their own grandchildren but not for the children of siblings, neighbours, friends or acquaintances. The analysis again showed reduced loneliness $(\beta=-0.05$, $\mathrm{p}<0.01)$. An increase in the number of important people with whom individuals have regular contact was also seen among those who only care for their own grandchildren $(\beta=0.96, p<0.001)$. A reduction in the social isolation score was no longer statistically significant. The complete results from the sensitivity analysis are shown in table 3 .

\section{DISCUSSION}

\section{Main findings}

Using data drawn from a representative sample of community-dwelling individuals aged $>40$ years in Germany, this study sought to examine whether there was an association between undertaking care of a grandchild
Table 2 Determinants of loneliness, social isolation and number of important people with whom individuals share regular contact: results of multiple linear regression

\begin{tabular}{|c|c|c|c|}
\hline & $\begin{array}{l}\text { (1) } \\
\text { Loneliness }\end{array}$ & $\begin{array}{l}\text { (2) Social } \\
\text { isolation }\end{array}$ & $\begin{array}{l}\text { (3) Social } \\
\text { network } \\
\text { size }\end{array}$ \\
\hline $\begin{array}{l}\text { Care of grandchild: yes } \\
\text { (reference category: no) }\end{array}$ & $\begin{array}{l}-0.06^{* *} \\
(0.02)\end{array}$ & $\begin{array}{l}-0.04^{*} \\
(0.02)\end{array}$ & $\begin{array}{l}1.02^{\star * \star} \\
(0.09)\end{array}$ \\
\hline $\begin{array}{l}\text { Gender: female (reference } \\
\text { category: male) }\end{array}$ & $\begin{array}{l}-0.13^{\star * \star} \\
(0.02)\end{array}$ & $\begin{array}{l}0.00 \\
(0.02)\end{array}$ & $\begin{array}{l}0.31^{\star * *} \\
(0.09)\end{array}$ \\
\hline Age in years & $\begin{array}{l}-0.01^{* \star *} \\
(0.00)\end{array}$ & $\begin{array}{l}-0.00^{\star \star *} \\
(0.00)\end{array}$ & $\begin{array}{l}-0.01^{*} \\
(0.01)\end{array}$ \\
\hline $\begin{array}{l}\text { Marital status: married and } \\
\text { living together with spouse } \\
\text { (reference category: other } \\
\text { (married, living separated from } \\
\text { spouse, divorced, widowed, } \\
\text { single)) }\end{array}$ & $\begin{array}{l}-0.07^{\star \star \star} \\
(0.02)\end{array}$ & $\begin{array}{l}-0.04 \\
(0.02)\end{array}$ & $\begin{array}{l}0.62^{\star \star \star} \\
(0.10)\end{array}$ \\
\hline $\begin{array}{l}\text { Monthly net household income } \\
\text { in Euros } / 1000\end{array}$ & $\begin{array}{l}-0.03^{* * *} \\
(0.01)\end{array}$ & $\begin{array}{l}-0.05^{\star \star \star} \\
(0.01)\end{array}$ & $\begin{array}{l}0.19^{\star \star \star} \\
(0.04)\end{array}$ \\
\hline Body mass index & $\begin{array}{l}-0.00^{\star} \\
(0.00)\end{array}$ & $\begin{array}{l}-0.00 \\
(0.00)\end{array}$ & $\begin{array}{l}0.01 \\
(0.01)\end{array}$ \\
\hline $\begin{array}{l}\text { Physical activity: at least once } \\
\text { a week (reference category: at } \\
\text { least once a week) }\end{array}$ & $\begin{array}{l}0.03 \\
(0.02)\end{array}$ & $\begin{array}{l}-0.04^{\star} \\
(0.02)\end{array}$ & $\begin{array}{l}0.51^{* * *} \\
(0.09)\end{array}$ \\
\hline $\begin{array}{l}\text { Self-rated health ( } 1=\text { very good } \\
\text { to } 5=\text { very bad) }\end{array}$ & $\begin{array}{l}0.02 \\
(0.01)\end{array}$ & $\begin{array}{l}0.02 \\
(0.01)\end{array}$ & $\begin{array}{l}-0.24^{\star * \star} \\
(0.06)\end{array}$ \\
\hline $\begin{array}{l}\text { Number of physical illnesses } \\
(0-11)\end{array}$ & $\begin{array}{l}0.02^{\star \star \star} \\
(0.00)\end{array}$ & $\begin{array}{l}0.03^{\star \star \star} \\
(0.01)\end{array}$ & $\begin{array}{l}0.10^{* \star *} \\
(0.03)\end{array}$ \\
\hline Depressive symptoms & $\begin{array}{l}0.02^{\star * \star} \\
(0.00)\end{array}$ & $\begin{array}{l}0.03^{\star * *} \\
(0.00)\end{array}$ & $\begin{array}{l}-0.01 \\
(0.01)\end{array}$ \\
\hline Constant & $\begin{array}{l}2.38^{\star \star \star} \\
(0.10)\end{array}$ & $\begin{array}{l}1.76^{\star \star \star} \\
(0.12)\end{array}$ & $\begin{array}{l}4.40^{\star \star \star} \\
(0.52)\end{array}$ \\
\hline Observations & 3849 & 3867 & 3923 \\
\hline $\mathrm{R}^{2}$ & 0.13 & 0.14 & 0.08 \\
\hline
\end{tabular}

Beta-coefficients are reported; robust standard errors in parentheses. Social isolation was measured using a scale by Bude and Lantermann (2006); values range from 1 to 4 , with higher values reflecting higher perceived social isolation. Loneliness was measured using a short version (Gierveld and Van Tilburg, 2006) of the De Jong Gierveld Loneliness Scale (Gierveld and Kamphuls, 1985); values range from 1 to 4, with higher values reflecting higher perceived loneliness. Number of important people in regular contact ranges between 0 and 9 . Depressive symptoms measured using the Centre for Epidemiological Depression Scale (CES-D), comprising 15 items (scores range from 0 to 45; higher scores refer to more severe depressive symptoms). In regression analysis, listwise deletion was used.

${ }^{\star * \star} \mathrm{p}<0.001,{ }^{* *} \mathrm{p}<0.01,{ }^{*} \mathrm{p}<0.05, \mathrm{t} \mathrm{p}<0.10$.

and subjective and objective measures of social relations, including loneliness, network size and social isolation. Controlling for various factors, undertaking care of a grandchild was associated with reduced loneliness and social isolation as well as an increased network size.

\section{Relation to previous studies}

To our knowledge, no study has sought to explore the association between supplementary grandchild care and 
Table 3 Determinants of loneliness, social isolation and number of important people with whom individuals share regular contact: results of sensitivity analysis

\begin{tabular}{|c|c|c|c|}
\hline & $\begin{array}{l}\text { (1) } \\
\text { Loneliness }\end{array}$ & $\begin{array}{l}\text { (2) Social } \\
\text { isolation }\end{array}$ & $\begin{array}{l}\text { (3) Social } \\
\text { network } \\
\text { size }\end{array}$ \\
\hline $\begin{array}{l}\text { Care of grandchild: yes } \\
\text { (reference category: no) }\end{array}$ & $\begin{array}{l}-0.05^{\star *} \\
(0.02)\end{array}$ & $\begin{array}{l}-0.03 \\
(0.02)\end{array}$ & $\begin{array}{l}0.98^{* * *} \\
(0.10)\end{array}$ \\
\hline $\begin{array}{l}\text { Gender: female (reference } \\
\text { category: male) }\end{array}$ & $\begin{array}{l}-0.13^{\star \star \star} \\
(0.02)\end{array}$ & $\begin{array}{l}0.00 \\
(0.02)\end{array}$ & $\begin{array}{l}0.33^{* \star *} \\
(0.09)\end{array}$ \\
\hline Age in years & $\begin{array}{l}-0.01^{\star * *} \\
(0.00)\end{array}$ & $\begin{array}{l}-0.00^{* * *} \\
(0.00)\end{array}$ & $\begin{array}{l}-0.01^{*} \\
(0.01)\end{array}$ \\
\hline $\begin{array}{l}\text { Marital status: married and living } \\
\text { together with spouse (reference } \\
\text { category: other (married, } \\
\text { living separated from spouse, } \\
\text { divorced, widowed, single)) }\end{array}$ & $\begin{array}{l}-0.08^{\star \star \star} \\
(0.02)\end{array}$ & $\begin{array}{l}-0.04 \dagger \\
(0.02)\end{array}$ & $\begin{array}{l}0.64^{\star \star \star} \\
(0.10)\end{array}$ \\
\hline $\begin{array}{l}\text { Monthly net household income } \\
\text { in Euros }\end{array}$ & $\begin{array}{l}-0.03^{\star \star \star} \\
(0.01)\end{array}$ & $\begin{array}{l}-0.05^{\star \star \star} \\
(0.01)\end{array}$ & $\begin{array}{l}0.20^{\star \star \star} \\
(0.04)\end{array}$ \\
\hline Body mass index & $\begin{array}{l}-0.00^{\star} \\
(0.00)\end{array}$ & $\begin{array}{l}-0.00 \\
(0.00)\end{array}$ & $\begin{array}{l}0.01 \\
(0.01)\end{array}$ \\
\hline $\begin{array}{l}\text { Physical activity: at least once a } \\
\text { week (reference category: less } \\
\text { than once a week) }\end{array}$ & $\begin{array}{l}0.03 \dagger \\
(0.02)\end{array}$ & $\begin{array}{l}-0.04^{*} \\
(0.02)\end{array}$ & $\begin{array}{l}0.49^{* * *} \\
(0.09)\end{array}$ \\
\hline $\begin{array}{l}\text { Self-rated health }(1=\text { very good } \\
\text { to } 5=\text { very bad) }\end{array}$ & $\begin{array}{l}0.02 \\
(0.01)\end{array}$ & $\begin{array}{l}0.02 \\
(0.01)\end{array}$ & $\begin{array}{l}-0.24^{\star \star \star} \\
(0.06)\end{array}$ \\
\hline $\begin{array}{l}\text { Number of physical illnesses } \\
(0-11)\end{array}$ & $\begin{array}{l}0.02^{\star \star \star} \\
(0.01)\end{array}$ & $\begin{array}{l}0.03^{* * *} \\
(0.01)\end{array}$ & $\begin{array}{l}0.10^{* * *} \\
(0.03)\end{array}$ \\
\hline Depressive symptoms & $\begin{array}{l}0.02^{* * *} \\
(0.00)\end{array}$ & $\begin{array}{l}0.03^{\star \star \star} \\
(0.00)\end{array}$ & $\begin{array}{l}-0.01 \\
(0.01)\end{array}$ \\
\hline Constant & $\begin{array}{l}2.38^{\star \star \star} \\
(0.10)\end{array}$ & $\begin{array}{l}1.76^{\star * \star} \\
(0.12)\end{array}$ & $\begin{array}{l}4.35^{\star \star \star} \\
(0.53)\end{array}$ \\
\hline Observations & 3793 & 3810 & 3866 \\
\hline $\mathrm{R}^{2}$ & 0.13 & 0.14 & 0.08 \\
\hline
\end{tabular}

Beta-coefficients are reported; robust standard errors in parentheses. Social isolation was measured using a scale by Bude and Lantermann (2006); values range from 1 to 4, with higher values reflecting higher perceived social isolation. Loneliness was measured using a short version (Gierveld and Van Tilburg, 2006) of the De Jong Gierveld Loneliness Scale (Gierveldand Kamphuls,1985); values range from 1 to 4, with higher values reflecting higher perceived loneliness. Number of important people in regular contact ranges between 0 and 9. Depressive symptoms measured using the Centre for Epidemiological Depression Scale (CES-D), comprising 15 items (scores range from 0 to 45; higher scores refer to more severe depressive symptoms). In regression analysis, listwise deletion was used.

${ }^{* * *} \mathrm{p}<0.001,{ }^{* *} \mathrm{p}<0.01,{ }^{*} \mathrm{p}<0.05,+\mathrm{p}<0.10$.

subjective and objective measures of social relations. In the most relevant article on this particular topic, Tsai $e t$ $a l$ showed that grandchild care can act as a protective factor against depression and feelings of loneliness. In their study this association was strongest among those who co-resided with their children and grandchildren. ${ }^{17}$ However, this study only used one part of the CES-D scale to assess feelings of loneliness rather than a comprehensive measure of loneliness. In studies pertaining to intense caregiving by grandparents, grandchild care was found to compromise the ability of grandparents to socialise. ${ }^{4647}$

As mentioned previously, the concepts of role strain and role enhancement have been used to explain the health and psychological implications of grandparental caregiving in a number of studies. ${ }^{14}$ Role enhancement theory posits that occupying many roles is beneficial to the health of the individual, as occupying many social roles enhances their personality, contributing to positive self-esteem. ${ }^{15}$ Our results suggest that role enhancement theory could be applied to those providing supplementary grandchild care. Assisting their families to balance work and family by providing supplementary grandchild care may boost grandparents' self-esteem, and may also facilitate ongoing positive relationships with their children and grandchildren. Moreover, caring for grandchildren may also expand the social circle of grandparents and allow for further opportunities to establish relationships with other parents or grandparents.

However, as grandparents become obligated to provide more intensive grandchild care, they may feel overburdened by the responsibility and less able to engage in other aspects of their lives. Indeed, perception of the nature of grandchild care, specifically whether it is perceived to be a voluntary task or not, has been suggested to be a key proponent of its effect on the health and well-being of grandparents. ${ }^{13}$ A mismatch between what grandparents expected to be their obligations and lifestyle during this period of their lives and the reality may cause stress as well as isolation from their peers. Similar logic has been applied to those who undertake custodial care of their grandchildren. ${ }^{48-51}$ Further research should be undertaken to elucidate the degree to which this would apply to grandparents undertaking the supplementary care of their grandchildren.

The grandparental role has also been conceptualised as an indication of social bonds. In their study on the health implications of grandparent caregiving, Chen and Liu state that caregiving constitutes an important aspect of grandparents' social network, and characterise this bond as a buffer against the negative and psychological consequences of ageing. ${ }^{52}$ The findings of our study appear to support this conceptualization. Those who actively engage in the grandparent role through the provision of supplementary childcare were found to feel less lonely, less socially isolated and have a larger social network than those who did not.

\section{Study strengths and limitations}

The study used a large nationally representative sample. The possibility of the presence of selection bias in this survey has been noted elsewhere, but has been determined to be small. ${ }^{25}$ Indeed, the distribution of demographic factors in the sample has been shown to be close to that of the German population. ${ }^{53}$

Previously validated and well-established tools were used for the measurement of loneliness and social isolation. Moreover, the study included both objective and 
subjective measures in its assessment of the outcome variable of social relations. In addition, a comprehensive range of possible confounders were controlled for in the regression analyses.

The study used listwise deletions to manage missing data, which could have led to a degree of bias.

It cannot be excluded that grandparents who care for their grandchildren consider their grandchildren as important people with whom they have regular contactthat is, that the grandchildren that grandparents care for (as well as the grandchild's primary caregiver) are included in the measure of social network size. Furthermore, it also cannot be excluded that living nearby to one's family also increases the likelihood of providing care to one's grandchildren as well as having a larger social network.

Due to its cross-sectional nature, it is difficult to draw conclusions regarding the direction of this relationship. Those who feel less lonely and socially isolated may be more likely to provide grandchild care. Moreover, those with a larger social network may feel better supported as well as more capable of providing supplementary grandchild care. A longitudinal study would elucidate the direction of this relationship. Moreover, a longitudinal study could provide detail as to whether undertaking grandchild care elicits a change in feelings of loneliness and social isolation, and influences the size of one's social network.

Finally, due to reasons of data availability, the provision of grandparent care is measured using a yes/no response. This means that the study is not necessarily restricted to those who provide supplementary grandparent care only. Furthermore, this study does not measure the quality of the time grandparents spend with grandchildren while providing care, nor does it measure how regularly and intensively grandparents provide care to their children. Of additional interest to our study would also be understanding whether the care of grandchildren involves both grandparents, or just one grandparent, as well as whether care is delivered in concert with the parents. Further research on the association between grandchild care that takes into account these aspects of grandparental care would extend our knowledge in this area.

\section{CONCLUSIONS}

This study identifies a positive association between caring for one's grandchild and one's social network. The care of a grandchild was also shown to be associated with a reduction in self-reported loneliness and social isolation. This study builds on the growing literature that explores the health, well-being and social implications of a growing number of grandparents undertaking supplementary care for their grandchildren. Longitudinal studies are required to strengthen the understanding of this association.
Contributors EQ, HHK, AH: Design and concept of analyses, preparation of data, statistical analysis and interpretation of data, preparing the manuscript. All authors critically reviewed the manuscript, provided significant editing of the article and approved the final manuscript.

Funding The authors have not declared a specific grant for this research from any funding agency in the public, commercial or not-for-profit sectors.

Competing interests None declared.

Patient consent for publication Not required.

Ethics approval The German Centre of Gerontology (DZA) resolved that ethics approval for the DEAS study was not necessary as the criteria for requiring an ethical statement were not met (namely, risk for the respondents, lack of information about the aims of the study, examination of patients). This is in accordance with the German Research Foundation-guidelines (Deutsche Forschungsgemeinschaft, DFG) available at: http://dfg.de/foerderung/faq/geistes_ sozialwissenschaften/ (only available in German language).

Provenance and peer review Not commissioned; externally peer reviewed.

Data availability statement All data relevant to the study are included in the article or uploaded as supplementary information.

Open access This is an open access article distributed in accordance with the Creative Commons Attribution Non Commercial (CC BY-NC 4.0) license, which permits others to distribute, remix, adapt, build upon this work non-commercially, and license their derivative works on different terms, provided the original work is properly cited, appropriate credit is given, any changes made indicated, and the use is non-commercial. See: http://creativecommons.org/licenses/by-nc/4.0/.

\section{ORCID iDs}

Eleanor Quirke http://orcid.org/0000-0002-7895-4790

André Hajek http://orcid.org/0000-0002-6886-2745

\section{REFERENCES}

1 Clarke L, Roberts C. The meaning of grandparenthood, and its contribution to the quality of life of older people. In: Walker A, Henessey C, eds. Growing older: quality of life in old age. Maidenhead, UK: Open University Press, 2004: 188-208.

2 Gattai FB, Musatti T. Grandmothers' involvement in grandchildren's care: attitudes, feelings, and emotions. Fam Relat 1999;48:35-42.

3 Igel C, Szydlik M. Grandchild care and welfare state arrangements in Europe. J Eur Soc Policy 2011;21:210-24.

4 Vandell DL, McCartney K, Owen MT, et al. Variations in child care by grandparents during the first three years. J Marriage Fam 2003;65:375-81.

5 Gray A. The changing availability of grandparents as carers and its implications for childcare policy in the UK. J Soc Policy 2005;34:557-77.

6 Hank K, Kreyenfeld M. A multilevel analysis of child care and women's fertility decisions in Western Germany. J Marriage Fam 2003;65:584-96.

7 Kuhlthau K, Mason KO. Market child care versus care by relatives: choices made by employed and nonemployed mothers. J Family Issues 1996;17:561-78.

8 Muller Z, Litwin H. Grandparenting and well-being: how important is grandparent-role centrality? Eur J Ageing 2011;8:109-18.

9 Guzman L. Grandma and grandpa taking care of the kids: patterns of involvement (Child Trends Research Brief 2004-017), 2004. Available: http://www.childtrends.org

10 Mahne K, Wolff J, Simonson J, et al. Altern Im Wandel: Zwei Jahrzehnte Deutscher Alterssurvey (DEAS, 2017.

11 Bulanda JR, Jendrek MP. Grandparenting roles and volunteer activity. GERONB 2016;71:129-40.

12 Albertini M, Kohli M. What childless older people give: is the generational link broken? Ageing Soc 2009;29:1261-74.

13 Triadó C, Villar F, Celdrán M, et al. Grandparents who provide auxiliary care for their grandchildren: satisfaction, difficulties, and impact on their health and well-being. $J$ Intergener Relatsh 2014;12:113-27.

14 Kim H-J, Kang H, Johnson-Motoyama M. The psychological well-being of grandparents who provide supplementary grandchild care: a systematic review. J Family Studies 2017;23:118-41.10.1080/13229400.2016.1194306

15 Goode WJ. A theory of role strain. Am Sociol Rev 1960;25:483-96.

16 Di Gessa G, Glaser K, Tinker A. The health impact of intensive and nonintensive grandchild care in Europe: new evidence from share. GERONB 2016;71:867-79. 
17 Tsai F-J, Motamed S, Rougemont A. The protective effect of taking care of grandchildren on elders' mental health? Associations between changing patterns of intergenerational exchanges and the reduction of elders' loneliness and depression between 1993 and 2007 in Taiwan. BMC Public Health 2013;13:567.

18 Hawkley LC, Cacioppo JT. Loneliness matters: a theoretical and empirical review of consequences and mechanisms. Ann Behav Med 2010;40:218-27.

19 Courtin E, Knapp M. Social isolation, loneliness and health in old age: a scoping review. Health Soc Care Community 2015;25:799-812.

20 Holt-Lunstad J, Smith TB, Baker M, et al. Loneliness and social isolation as risk factors for mortality: a meta-analytic review. Perspect Psychol Sci 2015;10:227-37.

21 Ong AD, Uchino BN, Wethington E. Loneliness and health in older adults: a mini-review and synthesis. Gerontology 2016;62:443-9.

22 Zaidi A, Gasior K, Hofmarcher MM. Active ageing index 2012: concept, methodology and final results. Vienna, 2013.

23 Rowe JW, Kahn RL. Successful aging 2.0: conceptual expansions for the 21st century. GERONB 2015;70:593-6.

24 Gerard J, Landry-Meyer L, Roe J. Grandparents raising grandchildren: the role of social support in coping with caregiving challenges, 2006.

25 Klaus D, Engstler H, Mahne K, et al. Cohort profile: the German ageing survey (DEAS). Int J Epidemiol 2017;46:1105-1105g

26 Neller K. Kooperation und Verweigerung: Eine Non-Response-Studie, 2005.

27 Farid S, Luqman M, Zeshan Saleem M, et al. Social isolation within family: an analysis of old age citizens, 2014.

28 Victor C, Scambler S, Bond J, et al. Being alone in later life: Ioneliness, social isolation and living alone. Rev Clin Gerontol 2000;10:407-17.

29 Victor CR, Scambler SJ, Bowling ANN, et al. The prevalence of, and risk factors for, loneliness in later life: a survey of older people in Great Britain. Ageing Soc 2005;25:357-75.

30 Moorer P, Suurmeijer TPBM. The effects of neighbourhoods on size of social network of the elderly and loneliness: a multilevel approach. Urban Studies 2001;38:105-18.

31 Wenger GC. Social networks and the prediction of elderly people at risk. Aging Ment Health 1997;1:311-20.

32 de Jong-Gierveld J, Kamphuls F. The development of a Rasch-type loneliness scale. Appl Psychol Meas 1985;9:289-99.

33 Jong-Gierveld J, van Tilburg TG, Dykstra PA. Loneliness and social isolation. In: Perlman AV D, ed. The Cambridge Handbook of personal relationships. Cambridge, UK: Cambridge University Press, 2006: 485-500.

34 Bude H, Lantermann E-D. Soziale exklusion und exklusionsempfinden. KZfSS Kölner Zeitschrift für Soziologie und Sozialpsychologie 2006;58:233-52.
35 Gracia E, Herrero J. Determinants of social integration in the community: an exploratory analysis of personal, interpersonal and situational variables. J Community Appl Soc Psychol 2004;14:1-15.

36 Scharf T, Phillipson C, Smith AE. Social exclusion of older people in deprived urban communities of England. Eur J Ageing 2005;2:76-87.

37 Van Regenmortel S, De Donder L, Dury S, et al. Social exclusion in later life: a systematic review of the literature. J Popul Ageing 2016;9:315-44.

38 Wang $\mathrm{Y}$, Marcotte DE. Golden years? The labor market effects of caring for grandchildren. J Marriage Fam 2007:69:1283-96.

39 Baydar N, Brooks-Gunn J. Profiles of grandmothers who help care for their grandchildren in the United States. Fam Relat 1998:47:385-93.

40 Attias-Donfut C, Ogg J, Wolff F-C. European patterns of intergenerational financial and time transfers. Eur J Ageing 2005;2:161-73.

41 Eggebeen DJ, Hogan DP. Giving between generations in American families. Human Nature 1990;1:211-32.

42 Silverstein M, Marenco A. How Americans enact the grandparent role across the family life course. J Fam Issues 2001;22:493-522.

43 Radloff LS. The CES-D Scale: a self-report depression scale for research in the general population. Appl Psychol Measurement 1977:1:385-401.

44 Luo Y, Hawkley LC, Waite LJ, et al. Loneliness, health, and mortality in old age: a national longitudinal study. Soc Sci Med 2012;74:907-14.

45 Perissinotto CM, Cenzer S I, Covinsky KE. Loneliness in older persons: a predictor of functional decline and death. Arch Intern Med 2012;172:1078-83.

46 Pruchno R. Raising grandchildren: the experiences of black and white grandmothers. Gerontologist 1999;39:209-21.

47 Minkler M. Intergenerational households headed by grandparents: contexts, realities, and implications for policy. J Aging Stud 1999:13:199-218.

48 Hayslip B, Kaminski PL. Grandparents raising their grandchildren: a review of the literature and suggestions for practice. Gerontologist 2005;45:262-9.

49 Jendrek MP. Grandparents who parent their grandchildren: effects on lifestyle. J Marriage Fam 1993;55:609-21.

50 Landry-Meyer L. Research into action: recommended intervention strategies for grandparent caregivers. Fam Relat 1999;48:381-9.

51 Minkler M, Miller Esme; Doriane; Driver D. Depression in grandparents raising grandchildren: results of a national longitudinal study. Arch Fam Med 1997;6:445-52.

52 Chen F, Liu G. The health implications of grandparents caring for grandchildren in China. J Gerontol Series B 2012;67B:99-112.

53 Mahne K, Wolff JK, Simonson J, et al. Altern Im Wandel: Zwei Jahrzehnte Deutscher Alterssurvey (DEAS). 1st edn. VS Verlag für Sozialwissenschaften, 2017: 389. 